\title{
Perceived Stress among Health Care Workers of an Emerging Infectious Covid-19 Outbreak in Indonesia
}

\author{
Shinta Novelia1*, Andi Mayasari Usman1, and Rian Adi Pamungkas² \\ 1Faculty of Health Sciences, Universitas Nasional, Jakarta \\ 2Department of Nursing, Faculty of Health Sciences, Esa Unggul University, Jakarta \\ *Corresponding author: rian.adi@esaunggul.ac.id \\ Type of the Paper (Article.) \\ Received: January 11, 2021; Accepted: April 5, 2021; Published: August 13, 2021 \\ https://doi.org/10.29253/achnr.2021.3962
}

\begin{abstract}
Background-During the pandemic of Covid-19 in the world, frontline health care workers have been responsible for tracing contacts of patients infected with coronavirus disease 2019 (COVID19). It has an impact on mental health of health care workers. This study aimed to investigate the perceived stress among health care workers who worked in health care facilities during the COVID-19 outbreak in Indonesia. Material and methods-A cross sectional study designed was applied in this study. The participants were midwives, nurses, pharmacists, pharmacist assistants, physicians, medical record staff, dental nurse, nutritionists and sanitarian. Demographic questionnaire was delivered to assess age, gender, marital status, job, workplace and work place province. Personal protective equipment was added to the questionnaire. A perceived stress scale was used to assess perceived stress. This research was conducted in the Health Centre, private clinic, non-referral covid-19 Hospital, referral covid-19 hospital, public health centre, and maternity clinics. A purposive sampling was used to get 196 respondents. Data were collected by electronic questionnaire. The ethical clearance was done by the letter from Faculty of Health Universitas Nasional. Results-Study questionnaires were completed by 196 respondents. The results showed that almost participants had a moderate stress (73\%). Most of the subjects were in the age group of 20-30 years old (43.9\%). Majority of the participants were female (89.8\%). Most of the participants were married (71.4\%). In 58.2\% of participants' job was midwife and in $25.5 \%$ of the participants' job was nurse. $50 \%$ of the participants worked in Public Health Centre and $20.9 \%$ of the participants worked in referral Covid-19 Hospital. In $26 \%$ of participants workplace Province was West Java, $17.9 \%$ of participants work place Province was Banten and $16.3 \%$ of participants work place Province was South Sulawesi. Conclusion-The COVID-19 outbreak in Indonesia resulted in increased stress for health care workers in Indonesia. Indonesia governments should improve interventions for preventing the spread of epidemics, promote disease treatment methods, and also offer psychological support especially for health care workers.
\end{abstract}

Keyword: health care worker; covid-19; perceived stress; nurses; and outbreak

\section{Introduction}

Covid-19 spreads in many countries in the world including Indonesia. The first two cases of covid19 found in Indonesia were on March 2, 2020. As of May 22 ${ }^{\text {nd, }} 2020$, it has increased to 20.162 cases with 1.278 deaths (Ministry of Health of Indonesia, 2020). Coronavirus is a group of viruses that can cause 
disease in animals or humans. Several types of coronavirus are known to cause respiratory infections in humans ranging from coughs to colds to more serious ones such as Middle East Respiratory Syndrome (MERS) and Severe Acute Respiratory Syndrome (SARS). A new type of Coronavirus has been found to cause COVID-19 (WHO, 2020; Zhu et al., 2020). The most common symptoms of COVID-19 are fever, fatigue, and dry cough. Some patients who suffer from COVID-19 may experience pain, ache, nasal congestion, runny nose, sore throat or diarrhea. Symptoms experienced are usually mild and appear gradually. Some infected people do not show any symptoms and still feel healthy. Majority infected people recover without the need for special treatment. Other symptoms are severe pain and difficulty breathing. Elderly people and people with pre-existing medical conditions such as high blood pressure, heart problems or diabetes, are more likely to experience more serious illness. More severe symptoms such as dyspnea, diarrhea, pneumonia and others have been reported. A previous study shows that majority of the patients who infected by Covid-19 were male, people with chronic comorbidities such as cardiovascular disease and diabetes and elderly (Bai, 2020; Li, 2020). WHO has declared the pandemic alarm on March 9, 2020 (WHO, 2020).

COVID-19 virus is transmitted between people through close contact and droplets (WHO, 2020). The people most at risk of infection are those who are in close contact with COVID-19 can be spread from person to person by sparks from the nose or mouth that comes out when infected people cough or COVID19 exhale. These sparks then fall on nearby objects and surfaces. People who touch the object or surface and then touch their eyes, nose or mouth, can be infected with COVID-19. Transmission of COVID-19 can also occur if people inhale a spark that comes out of cough or breaths of a person infected with COVID19.

This outbreak caused additional health problems such as stress, anxiety, depressive symptoms, insomnia, denial, anger among community especially nurses. Nurses were always the first line of caring patients in the outbreak. Nurses are the front line care professionals who stand near the patient's journey, such as COVID-19. Nurses have role in handling covid-19 pandemic including providing communication, information, and education about covid-19 and health management to the community, conducting rapid assessments, and direct services to sufferers. In Indonesia, the role of nurses in the form of nursing care is a series of interactions between nurses and sufferers and their environment to achieve the goal of meeting the needs and independence of patients. That is in accordance with the provisions of Law (Law) No. 38 of 2014 concerning Nursing. These roles include nursing care, counseling and counselors, managers, researchers, and implementing tasks in delegating authority and limited circumstances.

According to the Ministry of Health of Indonesia (2020), there were only 309,100 hospital beds in Indonesia, with most of them being located on Java Island. On top of that, there are less than 6,000 Intensive Care Unit (ICU) beds. In addition, mechanical ventilator is not widely available in rural settings and there is a shortage of protective gear for healthcare workers (Setiati \& Azwar (2020). Furthermore, additional precautions are required by health care workers to prevent transmission (WHO, 2020). The healthcare capacity depends on the health workers and personal protective equipment availability (Novelia, Sia, \& Songwathana, 2017; Novelia, \& Maneewat, 2020). Medical staff has been infected and have died during the COVID-19 epidemic in Indonesia. Thus, factors contribute to increased psychological stress of frontline medical staff in Indonesia which may have immediate or longpsychological consequences that may have acute or chronic somatic effects that result in conditions such as cardiac arrhythmia and myocardial infarction. In addition, medical staff experience of anxiety and the impact of stigma among those who were in direct contact with infected patients during Ebola outbreak (Torales, Higgins, Castaldelli-Maia \& Ventriglio, 2020).

The Indonesian government has implemented some public recommendations to contain COVID-19 transmission. The participations from the community are a vital role to overcome this pandemic condition. Vaccine of Covid-19 has not found until now. Scientists are still studying the characteristics of viruses and testing drugs in laboratories. To increase the productivity of nurses in handling pandemics, we need to pay attention to their capacities such as physical and mental health. Many nurses experience psychological distress when treating covid-19 patients directly or indirectly during the pandemic. There is still no specific antiviral treatment for COVID-19. A study recommends isolation and supportive care including oxygen therapy, fluid management, and antibiotics treatment for secondary bacterial infections. The strategy on initial management of COVID-19 should be addressed to the early recognition. 
Healthcare setting should implement control and prevention strategies of Covid-19 at the local and global levels (Cascella, Rajnik, Cuomo, Dulebohn, Di Napoli, 2010). If seen from the symptoms, it seems as influenza, but for medical analysis this virus is quite dangerous. Currently in 2020, the development of transmission of this virus is quite significant because its spread is worldwide and the whole country feels its effects including Indonesia. The spread of Covid-19 is so fast and deadly, transmission through physical contact is transmitted through the mouth, eyes and nose.

The covid-19 not only affects physical health but also mental health and wellbeing (Fiorillo \& Gorwood, 2020). Concerns about one's own health and that of their beloved ones (particularly elderly or suffering from any physical illness), as well as uncertainty about the future, can generate fear, depression, and anxiety. If these concerns are prolonged, it lead to increase the risk of serious and disabling mental health conditions among Health Care Workers (HCWs), including anxious disorders including panic, obsessive-compulsive, stress, and trauma-related disorders. The most significant stressors for those nurses are related to their physical working environment, i.e., workload (overtime work, frequent night shifts, unsuitable work/rest regimens, and work under pressure to have tasks done in a very short time) (Said \& El-Shafei, 2021). Occupational stress associated with COVID-19 is an important indicator of mental illness as it can lead to anxiety and depression in the confrontation of the co-occurrence of countless deaths, and long work shifts with the most diverse unknowns and demands.

During the acute phase of the pandemic, the increased level of stress and anxiety in the society due to COVID-19, it is essential that any emergency response should consider the component of mental health crisis management. There would be a specific need for HCW, especially mental health support, resilience training, and online support. Computer-assisted resilience training in HCW was significant benefit and merits further study under pandemic conditions (Maunder et al., 2010). Currently, Indonesia has inadequate personal protective equipment. Majority of health care worker used rain coat to replace personal protective equipment. They were feeling alarmed that they were running low on their usual stock of masks with no clear sign which they would receive PPE suitable for provide health care during COVID-19 outbreak (Smith, 2020). It might result on increased stress among health care workers. Thus, this study aimed to analyze perceived stress among health care workers of an emerging infectious Covid19 outbreak in Indonesia.

\section{Methodology}

A cross-sectional study design was applied in this study to determine perceived stress among Health Care Workers during covid-19 outbreak. We gathered data using the electronic questionnaire to avoid physically contact with large society. It is the best method to approach on large number of health care workers for data collection as well as it suitable in present conditions to prevention COVID-19 spreading. The Population in this study was healthcare workers who have been working at health care facilities such as Community Health center, Private clinic, Non referral Covid-19 hospital, and referral Covid-19 hospital which located in 15 provinces in Indonesia. The Province selected were West Java, Banten, Jambi, South Sulawesi, Lampung, West Sumatera, South Sulawesi, West Sulawesi, Riau, Bali, Papua, Central Sulawesi, Gorontalo and West Papua. This selection was based on the researcher's relation who worked as HCWs.

The sample size was calculated by using Lemeshow formula for undefined population and got 384 samples. Four hundred emails were sent to the prospective respondent, however the replies were 196 respondents (49\% response rate). One hundred and ninety six samples were enrolled to this study with the inclusion criteria were willingness to participate in this study, has been working as health care worker in the health care facilities, be able to read and communicate in Indonesia language, and be able to operate the mobile phone.

The variable in this study were respondents' characteristic (age, gender, marital status, occupation, work place and work place province), personal protective equipment, and perceived stress level. A Structure Questionnaire consisted of demographic data and assessment of availability of personal protective equipment. It was created by Google Forms for the survey. Perceived Stress Scale was used to assess perceived stress among health care workers (Cohen, Kessler \& Gordon, 1997). This was an existing instrument which had been tested for validity and reliability (Andreou et al., 2011). This was a 14-item instrument for measuring the perception of stress. Participants are asked to select how frequently they experienced each item within the past month on a 5-point Likert scale ranging from 0 (never) to 4 (very of ten). A 10-item revised version has been used in studies investigating stress among health care 
workers. There were 4 reverse-worded items (i.e., 4, 5, 7, 8), and those items (i.e., positive perception of stress) were reversed-coded. Total scores are obtained by summing all ratings of 10 items, with higher scores indicating greater levels of perceived stress. The researcher translated the original version of PSS into Indonesia language by using the Back Translation Technique (Douglas \& Craig, 2007). The step of back translation technique was started from English version to Indonesia and then back to English version. After completed of translation process, a comparing of the original text would be done to improve the accuracy of outward translation for users (Shigenobu, 2007).

The structure questionnaire was created by using Google Forms into Indonesia version and the link was generated and distributed among health care workers. It delivered by Emails and WhatsApp and talked with them to confirm eligible participants and asked to participate in the study. Data has been collected since the first week of April over a period of 2 weeks. Collected data were analyzed using descriptive statistics and inferential statistic. The descriptive statistic included frequency, percentage, Mean and Standard Deviation. The inferential statistic was done by a chi square test to analyze the relationship between demographic characteristic and perceived stress scale.

\section{Results \& Discussion}

\subsection{Results}

\subsubsection{Characteristics of participants}

Table 1 presents the demographic characteristic. The results showed that most of the subjects were female (89.8\%) with aged of 20-30 years old (43.9\%). More than half of the participants have been married (71.4\%). Nearly sixty percent (58.2\%) of participants worked as midwife and $25.5 \%$ of them were a nurse. Approximately of $50 \%$ participants have been working at community Health Centre. While $20.9 \%$ of them worked in referral Hospital for Covid-19. Regarding the area of working, around $26 \%$ of nurses from West Java, $17.9 \%$ of them from Banten and $16.3 \%$ come from South Sulawesi.

\subsubsection{Availability of Personal Protective Equipment}

Table 2 described the availability of personal protective equipment. The result showed that nearly a half of participants argued that the Personal Protective Equipment was neither adequate nor inadequate $(43.4 \%)$. A quarter $(25 \%)$ of the participant had inadequate of Personal Protective Equipment, and $24 \%$ of the participants had an adequate of Personal Protective Equipment.

\subsubsection{Distribution of Participants according to Perceived Stress Level}

Table 3 showed the level of perceived stress among health care workers. The results show that majority of participants had a moderate stress (73\%), while $20.9 \%$ of them were a low stress, and some of them were high stress (6.1\%). 
Table 1. Characteristics of participants.

\begin{tabular}{|c|c|c|}
\hline Demographic variables & Frequency & Percentage (\%) \\
\hline \multicolumn{3}{|l|}{ Age in year } \\
\hline 20-30 years old & 86 & 43.9 \\
\hline $31-40$ years old & 69 & 35.2 \\
\hline$>40$ years old & 41 & 20.9 \\
\hline \multicolumn{3}{|l|}{ Gender } \\
\hline Male & 20 & 10.2 \\
\hline Female & 176 & 89.8 \\
\hline \multicolumn{3}{|l|}{ Marital Status } \\
\hline Single & 56 & 28.6 \\
\hline Married & 140 & 71.4 \\
\hline \multicolumn{3}{|l|}{ Occupation } \\
\hline Midwife & 114 & 58.2 \\
\hline Nurse & 50 & 25.5 \\
\hline Pharmacist & 4 & 2.0 \\
\hline Pharmacist assistant & 8 & 4.1 \\
\hline Physician & 5 & 2.6 \\
\hline Medical record staff & 1 & 0.5 \\
\hline Dental nurse & 1 & 0.5 \\
\hline Nutritionist & 5 & 2.6 \\
\hline Sanitarian & 8 & 4.1 \\
\hline \multicolumn{3}{|l|}{ Work place } \\
\hline Primary care & 151 & 77 \\
\hline Secondary care & 45 & 23 \\
\hline \multicolumn{3}{|l|}{ Work place province } \\
\hline West java & 51 & 26 \\
\hline Banten & 35 & 17.9 \\
\hline Jambi & 8 & 4.1 \\
\hline DKI Jakarta & 12 & 6.1 \\
\hline Southeast Sulawesi & 10 & 5.1 \\
\hline Lampung & 3 & 1.5 \\
\hline West Sumatera & 15 & 7.7 \\
\hline South Sulawesi & 32 & 16.3 \\
\hline West Sulawesi & 3 & 1.5 \\
\hline Riau & 7 & 3.6 \\
\hline Bali & 4 & 2.0 \\
\hline Papua & 1 & 0.5 \\
\hline Central Sulawesi & 1 & 0.5 \\
\hline Gorontalo & 1 & 0.5 \\
\hline West Papua & 13 & 6.6 \\
\hline
\end{tabular}

Table 2. Availability of Personal Protective Equipment.

\begin{tabular}{lcc}
\hline Availability of PPE & Frequency & Percentage (\%) \\
\hline Very inadequate & 6 & 3.1 \\
Inadequate & 49 & 25.0 \\
Neither adequate nor inadequate & 85 & 43.4 \\
Adequate & 47 & 24.0 \\
Very adequate & 9 & 4.6 \\
\hline Total & 196 & 100 \\
\hline
\end{tabular}


Table 3. Perceived Stress Level.

\begin{tabular}{lcc}
\hline Perceived stress level & Frequency & Percentage (\%) \\
\hline Low stress & 41 & 20.9 \\
Moderate stress & 143 & 73.0 \\
High stress & 12 & 6.1 \\
\hline Total & 196 & $100 \%$ \\
\hline
\end{tabular}

\subsubsection{The Demographic Characteristics in Relation to Perceived Stress Level}

Table 4 shows that there was a significant relationship between age and perceived stress scale ( $p$ value $=0.003)$, there was a significant relationship between marital status and perceived stress scale $(p$ value $=0.003$ ), there was no significant relationship between gender and perceived stress scale ( $p$ value $=0.57$ ), there was no significant relationship between work place and perceived stress scale ( $\mathrm{p}$ value $=$ 0.95), there was no significant relationship between availability of PPE and perceived stress scale ( $p$ value $=0.003$ )

Table 4. Demographic Characteristics in Relation to Perceived Stress Level.

\begin{tabular}{|c|c|c|c|c|}
\hline \multirow[t]{2}{*}{ Variable } & \multicolumn{3}{|c|}{ Perceived stress scale } & \multirow[t]{2}{*}{$P$ value } \\
\hline & Low stress & Moderate stress & High stress & \\
\hline \multicolumn{5}{|c|}{ 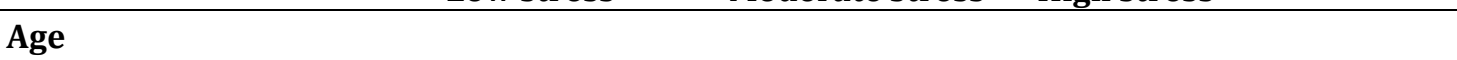 } \\
\hline $20-30$ years old & $10(11.6 \%)$ & 66 (76.7\%) & $10(11.6 \%)$ & \\
\hline $30-40$ years old & $14(24.6 \%)$ & $50(72.5 \%)$ & $2(2.9 \%)$ & 0.003 \\
\hline$>40$ years old & $14(34.1 \%)$ & $27(65.9 \%)$ & 0 & \\
\hline \multicolumn{5}{|l|}{ Gender } \\
\hline Female & $35(19.9 \%)$ & $130(73.9 \%)$ & $11(6.3 \%)$ & 0.57 \\
\hline Male & $6(30 \%)$ & $13(65 \%)$ & $1(5 \%)$ & \\
\hline \multicolumn{5}{|l|}{ Marital status } \\
\hline Married & $36(35.7 \%)$ & $100(71.4 \%)$ & $4(2.9 \%)$ & 0.01 \\
\hline Single & $5(8.9 \%)$ & $43(76.8 \%)$ & $8(14.3 \%)$ & \\
\hline \multicolumn{5}{|l|}{ Work place } \\
\hline Primary care & $31(20.5 \%)$ & $111(73.5 \%)$ & $9(6.0 \%)$ & 0.95 \\
\hline Secondary care & $10(22.2 \%)$ & $32(71.1 \%)$ & $3(6.7 \%)$ & \\
\hline \multirow{2}{*}{\multicolumn{5}{|c|}{$\begin{array}{l}\text { Availability of Personal } \\
\text { Protective Equipment }\end{array}$}} \\
\hline & & & & \\
\hline Very inadequate & $2(33.3 \%)$ & $4(66.7 \%)$ & $0(0 \%)$ & 0.27 \\
\hline Inadequate & $7(14.3 \%)$ & $35(71.4 \%)$ & $7(14.3 \%)$ & \\
\hline $\begin{array}{l}\text { Neither adequate nor } \\
\text { inadequate }\end{array}$ & $19(22.4 \%)$ & $62(72.9 \%)$ & $4(4.7 \%)$ & \\
\hline Adequate & $12(25.5 \%)$ & $34(72.3 \%)$ & $1(2.1 \%)$ & \\
\hline Very Adequate & $1(11.1 \%)$ & $8(88.9 \%)$ & $0(0 \%)$ & \\
\hline
\end{tabular}

\subsection{Discussions}

The results found that most of the participants were female (89.8\%) since majority of them are midwife (58.2\%). Half of participants have been working (50\%). Majority of the participants were in the age group of 20-30 years old. The results also showed that most of participants argued that the availability of Personal Protective Equipment was neither adequate nor inadequate (43.4\%). A previous study found that participants argued that the current protection measures are still lacking (31.3\%) (Cai, 2020). Personal protective equipment has become an important and emotive subject during the current coronavirus outbreak.

There are rational reasons, pre-clinical evidence about mental or psychological health risks from the corona's impact (Zulfa, 2020). Anxiety, stress or depression or fear and even panic from this corona case triggers an increased risk of psychological or mental health faced by health care workers in caring 
patients. Health care workers are the front line to face Covid-19 Pandemic. Previous studies found that the severe acute respiratory syndrome (SARS) and Middle East respiratory syndrome (MERS) outbreaks have shown that health care workers are not only under stress during epidemics, but also suffer psychologically long after the initial outbreak is over (Gee \& Skovdal, 2016; Khalid, Khalid, Qabajah, Barnard \& Qushmaq, 2016). In addition, epidemics have a significant impact on the psychological wellbeing of medical staff (Brooks, Dunn, Amlot, Rubin, Greenber, 2018). Similarly, this study showed that majority of participants (73\%) had a moderate level of perceived stress. Lazarus and Folkman (1984) stated that stress was not simply events that trigger negative emotional responses but also a twoway process where human interact with their environment. Stress can impact human well-being or functioning negatively when they perceive the situation as stressful and their resources are inadequate to handle stimuli of environmental.

There was no significant difference of participants' perceived stress in the group of workplaces ( $p=$ 0.95). It was found that $77 \%$ of the participants worked in primary care whih is Public Health Centre and $23 \%$ of the participants worked in the secondary care. Health care facilities are at the front in dealing with health problems in the community due to COVID-19. Public Health Centre which has been at the fore front of health services to reach the community in its working area, has increasingly played an important role in COVID-19 (Fong \& Wong, 2005).

The role of the Public Health Centre in Indonesia is conducting prevention, detection and response carried out in an integrated manner in providing services health during the COVID-19 pandemic (Paramitha, 2012; Syafrida \& Hartati, 2020). There were 10,134 health centers as the spearhead health services throughout Indonesia in 2019 (Paramitha, 2012). Health center is the frontline in breaking the transmission chain of COVID-19 because it is located in each district and has a regional concept. In the condition of this COVID-19 pandemic, Health Centre needs to make various efforts in handling prevention and restrictions transmission of infection. Thus, health care workers who work in the Public Health Centre tends to more stress compare to health care workers who work in other health care facilities.

This study found that there was no significant difference of perceived stress in the group of gender ( $p=-.071$ ). It might be the proportion of male and female in this study were not equal. Majority of participants were female (89.8\%). A previous study found that gender differences exist regarding the ability to cope with stress which may affect perceived stress (CDC, 2020; Cook, 2019; Li et al., 2020). Women are more likely than men to develop social and personal mechanisms to cope with stress (Novelia, Sitanggang \& Yulianti, 2018). Future study should conduct the comparison analysis of perceived stress by using equal number of gender. This study found that there was no significant difference of perceived stress in the group of job. However, the results claimed that almost participants were midwife. A previous study found that stress was greatest for emergency nurses, followed by emergency doctors, and then for healthcare assistants (Chou et al., 2019; Eisanbert, 2019). It is important for HCWs who stand in front line to maintain mental health during covid-19 pandemic.

\section{Conclusion}

The COVID-19 outbreak in Indonesia was significance increase workload and stress for health care workers. Staff support and the provision of facilities and equipment by hospital managers and the government are required to retain and encourage medical staff involvement in future epidemics. A strategy is needed to help health care workers. Indonesia governments should improve interventions for preventing the spread of epidemics, promote disease treatment methods, and also offer psychological support. In addition, by providing adequate personal protective equipment and the implementation of clear disease prevention guidelines, including hand washing, the use of face masks, and protective clothing might reduce the stress level of health care workers. It is important to safe mental health of health care workers as this can affect the success of healthcare delivery. It is vital to identify those have psychological distress so that timely intervention can be provided, and staff should be encouraged to step forward without fear of being blamed. The preventive measures also need to be taken to ensure that health care workers do not fall ill due to the virus during work exposure. This study recommend the frontline HCWs should be closely monitored as a high-risk group for depression and anxiety, and given proper training (e.g., COVID-19 knowledge, stress management, self-care) and some require psychological interventions. In addition, a strong family support may also increase frontline HCWs' resilience to stress and psychological symptoms during this covid-19 outbreak. 
This study has several limitations. This study was designed by using the cross-sectional observational study that included all health care workers who serve health care during pandemic and was short duration. The data from this study was based on subjective responses by using the questionnaire. This study has a small response rate and potential selection bias. Future study should be supported by objective measurements of stress and need to identify factors related perceived stress for example coping strategy.

\section{Acknowledgement}

We acknowledge Universitas Nasional which provided a partial funding for this research project.

\section{Ethical Approval}

Ethical issues are not involved in this paper.

\section{Conflict of interests}

All contributing authors declare no conflicts of interest.

\section{References}

Andreou, E., Alexopoulos, E. C., Lionis, C., Varvogli, L., Gnardellis, C., Chrousos, G. P., \& Darviri, C. (2011). Perceived stress scale: reliability and validity study in Greece. International journal of environmental research and public health, 8(8), 3287-3298.

Bai, Y., Yao, L., Wei, T., Tian, F., Jin, D. Y., Chen, L., \& Wang, M. (2020). Presumed asymptomatic carrier transmission of COVID-19. Jama, 323(14), 1406-1407.

Brooks, S. K., Dunn, R., Amlôt, R., Rubin, G. J., \& Greenberg, N. (2018). A systematic, thematic review of social and occupational factors associated with psychological outcomes in healthcare employees during an infectious disease outbreak. Journal of occupational and environmental medicine, 60(3), 248-257.

Cai, H., Tu, B., Ma, J., Chen, L., Fu, L., Jiang, Y., \& Zhuang, Q. (2020). Psychological Impact and Coping Strategies of Frontline Medical Staff in Hunan Between January and March 2020 During the Outbreak of Coronavirus Disease 2019 (COVID-19) in Hubei, China. Medical science monitor: international medical journal of experimental and clinical research, 26, e924171-1.

Cascella, M., Rajnik, M., Cuomo, A., Dulebohn, S. C., \& Di Napoli, R. (2020). Features, evaluation and treatment coronavirus (COVID-19). In Statpearls [internet]. StatPearls Publishing.

Chou, T. L., Ho, L. Y., Wang, K. Y., Kao, C. W., Yang, M. H., \& Fan, P. L. (2010). Uniformed service nurses' experiences with the severe acute respiratory syndrome outbreak and response in Taiwan. Nursing Clinics, 45(2), 179191.

Cohen, S., Kessler, R. C., \& Gordon, L. U. (Eds.). (1997). Measuring stress: A guide for health and social scientists. Oxford University Press on Demand.

Cook, T. M. (2020). Personal protective equipment during the coronavirus disease (COVID) 2019 pandemic-a narrative review. Anaesthesia.

Covid, C. D. C., COVID, C., COVID, C., Chow, N., Fleming-Dutra, K., Gierke, R., ... \& Roguski, K. (2020). Preliminary estimates of the prevalence of selected underlying health conditions among patients with coronavirus disease 2019-United States, February 12-March 28, 2020. Morbidity and Mortality Weekly Report, 69(13), 382.

Douglas, S. P., \& Craig, C. S. (2007). Collaborative and iterative translation: An alternative approach to back translation. Journal of International Marketing, 15(1), 30-43.

Fiorillo, A., \& Gorwood, P. (2020). The consequences of the COVID-19 pandemic on mental health and implications for clinical practice. European Psychiatry, 63(1).

Fong, P. S., \& Wong, K. C. (2005). Capturing and reusing building maintenance knowledge: A socio-technical perspective. In Knowledge management in the construction industry: A socio-technical perspective (pp. 67-89). IGI Global.

Gee, S., \& Skovdal, M. (2017). The role of risk perception in willingness to respond to the 2014-2016 West African Ebola outbreak: a qualitative study of international health care workers. Global health research and policy, 2(1), 1-10.

Khalid, I., Khalid, T. J., Qabajah, M. R., Barnard, A. G., \& Qushmaq, I. A. (2016). Healthcare workers emotions, perceived stressors and coping strategies during a MERS-CoV outbreak. Clinical medicine \& research, 14(1), 7-14.

Lazarus, R. S., \& Folkman, S. (1984). Stress, appraisal, and coping. Springer publishing company. 
Li, Q., Guan, X., Wu, P., Wang, X., Zhou, L., Tong, Y., ... \& Xing, X. (2020). Early transmission dynamics in Wuhan, China, of novel coronavirus-infected pneumonia. New England Journal of Medicine.

Maunder, R. G., Lancee, W. J., Mae, R., Vincent, L., Peladeau, N., Beduz, M. A., ... \& Leszcz, M. (2010). Computer-assisted resilience training to prepare healthcare workers for pandemic influenza: a randomized trial of the optimal dose of training. BMC health services research, 10(1), 1-10.

Ministry of Health of Indonesia. (2020). PETUNJUK TEKNIS PELAYANAN PUSKESMAS PADA MASA PANDEMI COVID19.

Novelia, S., Sia, W. S., \& Songwathana, P. (2017). Surgical Site Infection among Women Post Cesarean Section: An Integrative Review. Nurse Media Journal of Nursing, 7(1), 46-55.

Novelia, S., Sitanggang, T. W., \& Yulianti, A. (2018). Effects of yoga relaxation on anxiety levels among pregnant women. Nurse Media Journal of Nursing, 8(2), 86-95.

Novelia, S., \& Maneewat, K. (2020). Prevention and Management of Surgical Site Infection after Cardiac Surgery: A Case Study. Asian Community Health Nursing Research, 2(1).

Paramitha, N. M. (2012). Hubungan Stres dan Faktor Lainnya dengan Konsumsi Makanan Mahasiswa Departemen Arsitektur Fakultas Teknik Universitas Indonesia Tahun 2012 [The Relationship between Stress and Other Factors with Food Consumption of Students of the Department of Architecture, Faculty of Engineering, University of Indonesia in 2012]. Skripsi [Thesis]. Universitas Indonesia.

Prime Minister Ministry of Health (Jakarta, Indonesia). (2020). Letter to Pimpinan Kementerian/Lembaga; Gubernur; Bupati/ Walikota Seluruh Indonesia (Indonesia). 2020 Mar 16. 4 leaf. Protokol isolasi diri sendiri dalam penanganan coronavirus disease (covid-19). No.:HK.02.01/MENKES/202/2020.

Said, R. M., \& El-Shafei, D. A. (2021). Occupational stress, job satisfaction, and intent to leave: nurses working on front lines during COVID-19 pandemic in Zagazig City, Egypt. Environmental Science and Pollution Research, 28(7), 8791-8801.

Setiati, S., \& Azwar, M. K. (2020). COVID-19 and Indonesia. Acta Medica Indonesiana, 52(1), 84-89.

Shigenobu, T. (2007, July). Evaluation and usability of back translation for intercultural communication. In International Conference on Usability and Internationalization (pp. 259-265). Springer, Berlin, Heidelberg.

Smith, C. (2020). The structural vulnerability of healthcare workers during COVID-19: Observations on the social context of risk and the equitable distribution of resources. Social Science \& Medicine, 113119.

Syafrida, S., \& Hartati, R. (2020). Bersama melawan virus covid 19 di Indonesia. SALAM: Jurnal Sosial dan Budaya Syar-i, 7(6), 495-508.

Torales, J., O'Higgins, M., Castaldelli-Maia, J. M., \& Ventriglio, A. (2020). The outbreak of COVID-19 coronavirus and its impact on global mental health. International Journal of Social Psychiatry, 0020764020915212.

World Health Organization. (2020). Rational use of personal protective equipment (PPE) for coronavirus disease (COVID-19): interim guidance, 19 March 2020 (No. WHO/2019-nCoV/IPC PPE_use/2020.2). World Health Organization.

World Health Organization. (2020). Clinical management of severe acute respiratory infection (SARI) when COVID19 disease is suspected: interim guidance, 13 March 2020 (No. WHO/2019-nCoV/clinical/2020.4). World Health Organization.

World Health Organization. (2020). Laboratory testing for coronavirus disease 2019 (COVID-19) in suspected human cases: interim guidance, 2 March 2020 (No. WHO/COVID-19/laboratory/2020.4). World Health Organization.

Zulva, T. N. I. (2020). Covid-19 Dan Kecenderungan Psikosomatis. J. Chem. Inf. Model, 1-4.

Zhu, N., Zhang, D., Wang, W., Li, X., Yang, B., Song, J., ... \& Niu, P. (2020). A novel coronavirus from patients with pneumonia in China, 2019. New England Journal of Medicine. 